\title{
Methylene blue-induced serotonin syndrome after left ventricular assist device implantation: A case report and literature review
}

\author{
Leif-Erik D. Schumacher, BS, ${ }^{\mathrm{a}}$ Vanessa Blumer, MD, ${ }^{\mathrm{b}}$ and Sandra V. Chaparro, $\mathrm{MD},{ }^{\mathrm{c}}$ Miami, Fla
}

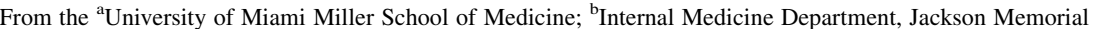
Hospital, University of Miami; and ${ }^{\mathrm{c}}$ Division of Cardiovascular Medicine, University of Miami Hospital, Miami, Fla.

Disclosures: Dr Chaparro is a consultant for Abbott and received research support from Medtronic on an unrelated project. All other authors have nothing to disclose with regard to commercial support.

The authors attest to having full freedom to explore data, analyze results independently, and had sole authority in deciding to submit the material for publication.

Received for publication Feb 15, 2017; revisions received April 21, 2017; accepted for publication May 17, 2017; available ahead of print June 24, 2017.

Address for reprints: Sandra V. Chaparro, MD, Cardiovascular Medicine, University of Miami Miller School of Medicine, Clinical Research Building, Room 1110, 1120 NW 14th St, Miami, FL 33136 (E-mail: schaparro@ miami.edu).

J Thorac Cardiovasc Surg 2017;154:e39-43

$0022-5223 / \$ 36.00$

Copyright $(2017$ by The American Association for Thoracic Surgery

http://dx.doi.org/10.1016/j.jtcvs.2017.05.053
}

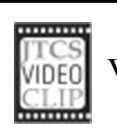

Video clip is available online.

Serotonin syndrome is a life-threatening condition of serotonin excess in the central nervous system. We report the first case to occur after a routine left ventricular assist device (LVAD) implantation. Through a systematic review of the literature, we then describe the characteristics of all previous patients with serotonin syndrome after cardiovascular procedures and identify common threads that elucidate serotonin syndrome's recent emergence.

\section{CASE PRESENTATION}

A 60-year-old Hispanic man with a medical history of coronary artery bypass graft, hypertension, atrial fibrillation, obesity, obstructive sleep apnea, depression, and ischemic cardiomyopathy with ejection fraction $10 \%$ to $15 \%$ was admitted for heart failure exacerbation. Right and left heart catheterizations showed nonobstructive coronary artery disease and increased right-sided heart pressures. He subsequently developed cardiogenic shock requiring intra-aortic balloon pump and inotropic support with milrinone. Eleven days later, he underwent LVAD implantation. General anesthesia required fentanyl, midazolam, rocuronium, dexmedetomidine, and etomidate. He required vasopressor and inotropic support with norepinephrine, epinephrine, and milrinone. He also received prophylactic antibiotic treatment with vancomycin, cefepime, anesthesia.

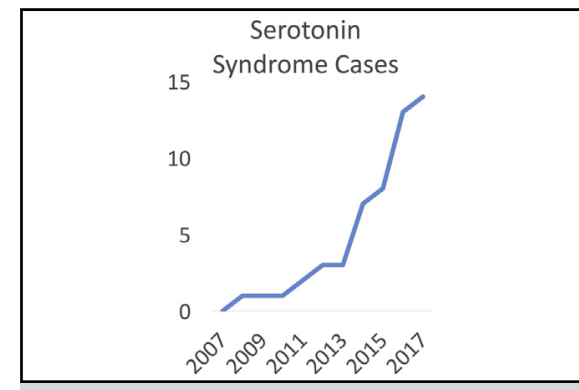

Total number of serotonin syndrome cases in cardiology literature over time.

Central Message

Serotonin syndrome recently has emerged in cardiology literature. All reported cases have been triggered by fentanyl and/or methylene blue and the vast majority were preceded by antidepressants.

See Editorial Commentary page e45.

and fluconazole. The operation was successful with no complications, and the patient recovered appropriately from

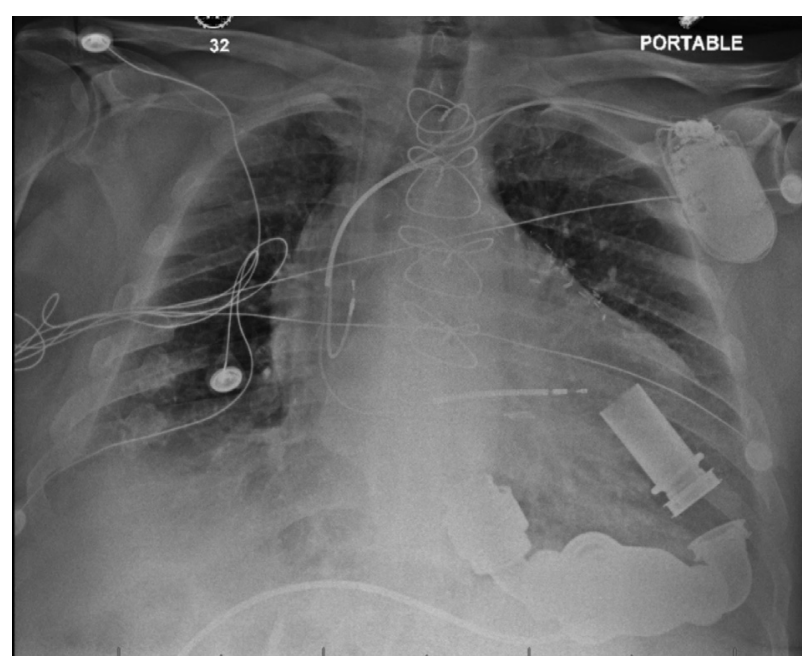

VIDEO 1. A video describing the unique aspects of this case report followed by the key findings from a review of all serotonin syndrome cases in the cardiology literature. Video available at: http://www.jtcvsonline.org/ article/S0022-5223(17)31103-0/addons. 
TABLE 1. Serotonin syndrome case summaries

\begin{tabular}{|c|c|c|c|c|c|c|c|c|}
\hline Published & Age, $y$ & Patient & $\begin{array}{c}\text { Prehospital } \\
\text { 5HT agent }\end{array}$ & $\begin{array}{c}\text { In-patient 5HT } \\
\text { agent }\end{array}$ & Procedure & Symptoms & Treatment & Outcome \\
\hline $\begin{array}{l}\text { Shanmugam } \\
\text { and } \\
\text { colleagues } \\
2008^{1}\end{array}$ & 49 & Female & $\begin{array}{l}\text { Paroxetine } \\
\text { PO } 40 \mathrm{mg} \text { QD }\end{array}$ & $\begin{array}{l}\text { Fentanyl } 5 \mu \mathrm{g} / \mathrm{kg} \text {, } \\
\text { Fentanyl } 13 \mu \mathrm{g} / \mathrm{kg}, \\
\text { MB } 1 \mathrm{mg} / \mathrm{kg} \\
\quad \times 2 \text { doses }\end{array}$ & $\begin{array}{l}\text { Mitral valve } \\
\text { replacement }\end{array}$ & $\begin{array}{l}\text { Fever }\left(40^{\circ} \mathrm{C}\right) \text {, } \\
\text { confusion, agitation, } \\
\text { hypertension, } \\
\text { myoclonic jerks, } \\
\text { fine tremors, rigidity, } \\
\text { hyperreflexia }\end{array}$ & $\begin{array}{l}\text { Intubation with } \\
\text { ventilation and } \\
\text { paralysis for } 24 \mathrm{~h} \text {, } \\
\text { cyproheptadine } \\
12 \mathrm{mg} \text { one dose and } \\
2 \mathrm{mg} \text { every second } \\
\text { hour for } 48 \mathrm{~h}, \\
\text { discontinued } \\
\text { serotonergic agents }\end{array}$ & $\begin{array}{l}\text { Extubation after } \\
\text { 1wk. Slow but } \\
\text { complete recovery. }\end{array}$ \\
\hline $\begin{array}{l}\text { Choudhury } \\
\text { and } \\
\text { colleagues } \\
2011^{2}\end{array}$ & 57 & Female & $\begin{array}{l}\text { Fluoxetine } \\
\qquad 60 \mathrm{mg} \text { PO QD }\end{array}$ & $\begin{array}{l}\text { Fentanyl (anesthesia), } \\
\text { fentanyl } 1 \mu \mathrm{g} / \mathrm{kg} \\
\text { (postop) }\end{array}$ & CABG & $\begin{array}{l}\text { Hypertension, agitation, } \\
\text { diaphoresis, } \\
\text { myoclonus, } \\
\text { headache, vomiting }\end{array}$ & $\begin{array}{l}\text { Diazepam } 5 \mathrm{mg} \text { IV, } \\
\text { cyproheptadine } \\
20 \mathrm{mg} \text { PO, } \\
\text { discontinued } \\
\text { serotonergic agents }\end{array}$ & $\begin{array}{l}\text { Symptom } \\
\text { improvement } \\
\text { within } 4 \mathrm{~h} \text { and } \\
\text { complete resolution } \\
\text { within } 30 \mathrm{~h} \text {. }\end{array}$ \\
\hline $\begin{array}{l}\text { Grubb and } \\
\text { colleagues, } \\
2012^{3}\end{array}$ & 60 & Male & $\begin{array}{l}\text { Escitalopram } \\
20 \text { mg PO QD, } \\
\text { Trazodone } \\
100 \mathrm{mg} \text { QHS }\end{array}$ & $\begin{array}{c}\mathrm{MB} 1 \mathrm{mg} / \mathrm{kg} \mathrm{IV}, \mathrm{MB} \\
0.5 \mathrm{mg} / \mathrm{kg} / \mathrm{h} \mathrm{IV}\end{array}$ & $\begin{array}{l}\text { Heart } \\
\quad \text { transplantation }\end{array}$ & $\begin{array}{l}\text { Fever }\left(40^{\circ} \mathrm{C}\right), \\
\text { delayed recovery } \\
\text { from anesthesia, } \\
\text { ocular clonus, } \\
\text { mydriasis, nystagmus, } \\
\text { myoclonic jerks, } \\
\text { shivering, } \\
\text { hypertonicity }\end{array}$ & $\begin{array}{l}\text { Midazolam for } 24 \mathrm{~h} \text {, } \\
\text { delayed extubation, } \\
\text { discontinued } \\
\text { serotonergic agents }\end{array}$ & $\begin{array}{l}\text { No neurologic } \\
\text { deficits after } 48 \mathrm{~h} \text {, } \\
\text { discharged home } \\
17 \text { d posttransplant. }\end{array}$ \\
\hline $\begin{array}{l}\text { Fugate and } \\
\text { colleagues, } \\
2014^{4}\end{array}$ & 58 & Male & $\begin{array}{l}\text { Sertraline } \\
50 \mathrm{mg} \text { PO QD }\end{array}$ & $\begin{array}{l}\text { Fentanyl } 75-150 \mu \mathrm{g} / \mathrm{h} \text {, } \\
\text { Tramadol }\end{array}$ & $\begin{array}{l}\text { Coronary } \\
\text { angiography, } \\
\text { therapeutic } \\
\text { hypothermia }\end{array}$ & $\begin{array}{l}\text { Fever }\left(38.8^{\circ} \mathrm{C}\right), \\
\text { Unable to follow } \\
\text { commands, } \\
\text { hypertension, } \\
\text { agitation, rigidity, } \\
\text { fasciculations, } \\
\text { tremors, clonus }\end{array}$ & $\begin{array}{l}\text { Discontinued } \\
\text { serotonergic agents }\end{array}$ & $\begin{array}{l}\text { Full neurologic } \\
\text { recovery over } \\
\text { several weeks. }\end{array}$ \\
\hline $\begin{array}{l}\text { Fugate and } \\
\text { colleagues, } \\
2014^{4}\end{array}$ & 36 & Male & Paroxetine & Fentanyl $25 \mu \mathrm{g} / \mathrm{h}$ & $\begin{array}{l}\text { Coronary } \\
\text { angiography, } \\
\text { therapeutic } \\
\text { hypothermia }\end{array}$ & $\begin{array}{l}\text { Fever }\left(38.5^{\circ} \mathrm{C}\right) \\
\text { hypertension, } \\
\text { agitation, rigidity, } \\
\text { hyperreflexia, clonus }\end{array}$ & $\begin{array}{l}\text { Surface cooling device, } \\
\text { hydromorphone, } \\
\text { continued intubation } \\
\text { for } 9 \mathrm{~d} \text {, discontinued } \\
\text { serotonergic agents }\end{array}$ & $\begin{array}{l}\text { Mild persistent } \\
\text { encephalopathy at } \\
\text { discharge to brain } \\
\text { rehabilitation on } \\
\text { day } 20 .\end{array}$ \\
\hline $\begin{array}{l}\text { Fugate and } \\
\text { colleagues } \\
2014^{4}\end{array}$ & 53 & Male & - & Fentanyl $125 \mu \mathrm{g} / \mathrm{h}$ & $\begin{array}{l}\text { Therapeutic } \\
\text { hypothermia }\end{array}$ & $\begin{array}{c}\text { Fever, hypertension, } \\
\text { agitation, rigidity, } \\
\text { hyperreflexia, } \\
\text { tremors, clonus, } \\
\text { rhabdomyolysis }\end{array}$ & $\begin{array}{l}\text { Cooling device, } \\
\text { cyproheptadine } 8 \mathrm{mg} \\
\text { every } 6 \mathrm{~h} \text {, diazepam } \\
10 \mathrm{mg} \text { IV every } 6 \mathrm{~h} \text {, } \\
\text { dexmedetomidine, } \\
\text { continued intubation } \\
\text { for } 7 \mathrm{~d} \text {, discontinued } \\
\text { fentanyl }\end{array}$ & $\begin{array}{c}\text { Neurologic resolution } \\
\text { before discharge. }\end{array}$ \\
\hline $\begin{array}{c}\text { Hanna and } \\
\text { Clark, } \\
2014^{5}\end{array}$ & 62 & Male & Escitalopram & $\begin{array}{l}\text { Fentanyl, } \\
\qquad \text { MB } 2 \mathrm{mg} / \mathrm{kg}\end{array}$ & 4-vessel CABG & $\begin{array}{l}\text { Fever }\left(41.5^{\circ} \mathrm{C}\right) \text {, no } \\
\text { recovery from } \\
\text { anesthesia, horizontal } \\
\text { nystagmus, rigidity, } \\
\text { cardiac arrest }\end{array}$ & $\begin{array}{l}\text { Delayed extubation, } \\
\text { acetaminophen, ice } \\
\text { packs, discontinued } \\
\text { serotonergic agents }\end{array}$ & $\begin{array}{l}\text { No apparent deficits } \\
\text { at discharge } 2 \mathrm{wk} \\
\text { post-CABG. }\end{array}$ \\
\hline $\begin{array}{l}\text { Smith and } \\
\text { colleagues, } \\
2015^{6}\end{array}$ & 59 & Female & $\begin{array}{l}\text { Venlafaxine } \\
100 \mathrm{mg} \text { BID } \\
\text { (switched to } \\
225 \mathrm{mg} \text { QD and } \\
\text { then to } 187.5 \mathrm{mg} \\
\text { QD in hospital), } \\
\text { Trazodone } \\
100 \text { mg daily } \\
\text { as needed }\end{array}$ & $\begin{array}{l}\text { MB } 2 \mathrm{mg} / \mathrm{kg} \mathrm{IV} \text {, } \\
\text { Trazodone } \\
100 \mathrm{mg} 1 \mathrm{~d} \\
\text { before surgery }\end{array}$ & $\begin{array}{l}\text { CABG, mitral } \\
\text { valve repair }\end{array}$ & $\begin{array}{l}\text { Fever }\left(38.7^{\circ} \mathrm{C}\right), \\
\text { generalized tremors, } \\
\text { rhythmic perioral } \\
\text { twitching, clonus, } \\
\text { rigidity, nystagmus }\end{array}$ & $\begin{array}{l}\text { Lorazepam } 1 \mathrm{mg} \text { IV } \\
\text { every } 12 \mathrm{~h}, \\
\text { levetiracetam } \\
1000 \mathrm{mg} \text { IV every } \\
12 \mathrm{~h}, \text { Midazolam } \\
1-5 \mathrm{mg} / \mathrm{h}, \text { Fentanyl* } \\
12.5-75 \mu \mathrm{g} / \mathrm{h}, \\
\text { reintubation, } \\
\text { withheld venlafaxine, } \\
\text { trazodone, and MB. }\end{array}$ & $\begin{array}{l}\text { Cognitive dysfunction } \\
\text { slowly resolved } \\
\text { over } 2 \text { wk post- } \\
\text { CABG. }\end{array}$ \\
\hline
\end{tabular}




\begin{tabular}{|c|c|c|c|c|c|c|c|c|}
\hline Published & Age, $y$ & Patient & $\begin{array}{c}\text { Prehospital } \\
\text { 5HT agent }\end{array}$ & $\begin{array}{c}\text { In-patient 5HT } \\
\text { agent }\end{array}$ & Procedure & Symptoms & Treatment & Outcome \\
\hline $\begin{array}{l}\text { Hencken and } \\
\text { colleagues, } \\
2016^{7}\end{array}$ & 50 & Female & $\begin{array}{l}\text { Citalopram } \\
20 \mathrm{mg} \text { PO }\end{array}$ & $\begin{array}{c}\text { MB } 2 \mathrm{mg} / \mathrm{kg} \mathrm{IV,} \mathrm{MB} \\
0.5 \mathrm{mg} / \mathrm{kg} / \mathrm{h} \mathrm{IV}\end{array}$ & $\begin{array}{l}\text { Aortic valve } \\
\text { replacement, } \\
\text { LVAD }\end{array}$ & $\begin{array}{l}\text { Fever, fixed dilated } \\
\text { pupils, shivering, } \\
\text { ocular and extremity } \\
\text { clonus, fasciculations, } \\
\text { tremor, hyperreflexia, } \\
\text { hypertonia }\end{array}$ & $\begin{array}{l}\text { Propofol, meperidine, } \\
\text { discontinued } \\
\text { serotonergic agents }\end{array}$ & $\begin{array}{l}\text { Neurologic } \\
\text { improvement } \\
\text { over } 24-48 \mathrm{~h} \text {. } \\
\text { Discharged to } \\
\text { rehabilitation } \\
\text { facility } 54 \mathrm{~d} \\
\text { after surgery. }\end{array}$ \\
\hline $\begin{array}{l}\text { Martino and } \\
\text { colleagues, } \\
2016^{8}\end{array}$ & 65 & Female & $\begin{array}{l}\text { Paroxetine } \\
20 \mathrm{mg} \text { PO QD }\end{array}$ & $\begin{array}{l}\text { Fentanyl } 950 \mu \mathrm{g}, \\
\text { MB } 100 \mathrm{mg} \times 2 \\
\text { doses }\end{array}$ & $\begin{array}{l}\text { Aortic valve } \\
\text { replacement, } \\
\text { Ostium } \\
\text { secundum } \\
\text { atrial septal } \\
\text { defect repair }\end{array}$ & $\begin{array}{l}\text { Fever }\left(41^{\circ} \mathrm{C}\right), \\
\text { generalized tonic- } \\
\text { clonic seizure, lateral } \\
\text { nystagmus, muscle } \\
\text { rigidity, coma } 30 \mathrm{~h}\end{array}$ & $\begin{array}{l}\text { Benzodiazepines, } \\
\text { discontinued } \\
\text { serotonergic agents }\end{array}$ & $\begin{array}{l}\text { Discharged from } \\
\text { ICU within } 24 \mathrm{~h} \\
\text { of waking from } \\
\text { a 30-h coma. }\end{array}$ \\
\hline $\begin{array}{l}\text { Martino and } \\
\text { colleagues, } \\
2016^{8}\end{array}$ & 82 & Female & $\begin{array}{l}\text { Citalopram } \\
20 \mathrm{mg} \text { PO QD }\end{array}$ & $\begin{array}{l}\text { Fentanyl } 700 \mu \mathrm{g}, \\
\text { MB } 100 \mathrm{mg} \times 2 \\
\text { doses }\end{array}$ & $\begin{array}{l}\text { Aortic valve } \\
\text { replacement }\end{array}$ & $\begin{array}{l}\text { Diaphoresis, Lateral } \\
\text { nystagmus, coma } \\
34 \mathrm{~h}\end{array}$ & $\begin{array}{l}\text { Benzodiazepines, } \\
\text { discontinued } \\
\text { serotonergic agents, }\end{array}$ & $\begin{array}{l}\text { Discharged from } \\
\text { ICU within } 24 \mathrm{~h} \\
\text { of waking from } \\
\text { a 34-h coma. }\end{array}$ \\
\hline $\begin{array}{l}\text { Martino and } \\
\text { colleagues } \\
2016^{8}\end{array}$ & 74 & Female & $\begin{array}{l}\text { Sertraline } \\
25 \text { mg PO QD, } \\
\text { Trazodone, } \\
\text { amisulpride }\end{array}$ & $\begin{array}{l}\text { Fentanyl } 1000 \mu \mathrm{g}, \\
\text { MB } 100 \mathrm{mg} \times 2 \\
\text { doses }\end{array}$ & $\begin{array}{l}\text { Mitral and aortic } \\
\text { valve } \\
\text { replacements, } \\
\text { tricuspid repair, } \\
\text { radiofrequency }\end{array}$ & $\begin{array}{l}\text { Agitation, lateral } \\
\text { nystagmus, coma } \\
112 \mathrm{~h}\end{array}$ & $\begin{array}{l}\text { Benzodiazepines, } \\
\text { discontinued } \\
\text { serotonergic agents }\end{array}$ & $\begin{array}{l}\text { Subsequent } \\
\text { cardiogenic } \\
\text { shock and sepsis } \\
\text { resulting in } 262 \mathrm{~h} \\
\text { in ICU. }\end{array}$ \\
\hline $\begin{array}{c}\text { Wolvetang and } \\
\text { colleagues } \\
2016^{9}\end{array}$ & 64 & Female & Paroxetine & $\begin{array}{l}\text { MB } 2 \mathrm{mg} / \mathrm{kg}, \\
\text { granisetron } 1 \mathrm{mg}\end{array}$ & $\begin{array}{c}\text { Mitral valve } \\
\text { repair }\end{array}$ & $\begin{array}{c}\text { Fever }\left(40.5^{\circ} \mathrm{C}\right), \\
\text { nystagmus, } \\
\text { hypertonicity, } \\
\text { mydriasis }\end{array}$ & $\begin{array}{l}\text { Midazolam for } \\
\text { reintubation, passive } \\
\text { cooling, haloperidol }\end{array}$ & $\begin{array}{l}\text { Complete neurologic } \\
\text { recovery } 12 \mathrm{~d} \text { after } \\
\text { surgery. }\end{array}$ \\
\hline $\begin{array}{l}\text { Current study, } \\
2017\end{array}$ & 60 & $\begin{array}{l}\text { Male, } \\
\text { Hispanic }\end{array}$ & $\begin{array}{l}\text { Escitalopram } \\
10 \mathrm{mg} \text { PO QD } \\
\text { (replaced in } \\
\text { hospital with } \\
\text { citalopram } \\
20 \mathrm{mg} \text { PO) }\end{array}$ & $\begin{array}{l}\text { Fentanyl } 750 \mu \mathrm{g}, \\
\text { MB } 0.5 \mathrm{mg} / \mathrm{kg} / \mathrm{h} \\
\text { IV }\end{array}$ & LVAD & $\begin{array}{l}\text { Fever }\left(39.8^{\circ} \mathrm{C}\right), \\
\text { acute mental status } \\
\text { change, repetitive eye } \\
\text { movements, } \\
\text { inducible clonus, } \\
\text { hypertonia, } \\
\text { hyperreflexia, } \\
\text { oral automatisms }\end{array}$ & $\begin{array}{l}\text { Lorazepam } 2 \mathrm{mg} \\
\text { every } 4 \mathrm{~h}, \\
\text { discontinued } \\
\text { serotonergic agents }\end{array}$ & $\begin{array}{l}\text { Full resolution in } \\
1 \text { wk. Discharged } \\
\text { home } 27 \mathrm{~d} \\
\text { post-LVAD. }\end{array}$ \\
\hline
\end{tabular}

$5 H T$, Serotonin; $P O$, per os (by mouth); $Q D$, daily; $M B$, methylene blue; postop, postoperative; $C A B G$, coronary artery bypass graft; $I V$, intravenously; $Q H S$, every bedtime; $B I D$, twice daily; $L V A D$, left ventricular assist device; $I C U$, intensive care unit. *Serotonergic agent; highly contraindicated in serotonin syndrome

The first night of the postoperative period, the patient became severely hypotensive despite vasopressor support. LVAD pump parameters were optimal, and no evidence of device malfunction was documented. Because of the copious blood products, vasopressors, inotropes, and crystalloids administered during LVAD placement, methylene blue (MB) was administered instead of fluids to increase systemic vascular resistance.

The subsequent morning, the patient was noted to be febrile and tachycardic with acute mental status change, repetitive horizontal eye movements, inducible sustained clonus, hypertonia, hyperreflexia in all extremities, and oral automatisms. Serotonin syndrome was suspected, and his medication list was reviewed for serotonergic agents. Notably, escitalopram $10 \mathrm{mg}$ was taken daily before his hospitalization and substituted with citalopram $20 \mathrm{mg}$ on admission 2 weeks previously. Serotonergic agents were withheld while alternative causes for his neurologic symptoms were investigated. A computed tomography scan showed no acute intracranial hemorrhage. An electroencephalogram showed no seizures or epileptiform discharges but did show an absent posterior background with continuous irregular diffuse delta/theta slowing consistent with severe encephalopathy. Bronchoalveolar lavage and urine cultures had no growth after several days. No overt abnormalities were seen on metabolic panels to account for his symptoms. He was treated with standing doses of lorazepam. After 2 days, his symptoms had notably improved. Within 1 week, his neurologic symptoms had fully resolved. He was discharged home 3 weeks later.

\section{DISCUSSION}

This article presents the first case of serotonin syndrome after a routine LVAD implantation and is the fourteenth case of serotonin syndrome in cardiology literature (Video 1). The 14 cases, along with their characteristics, etiology, symptomatology, treatment, and outcome, are presented 
in Table 1. ${ }^{1-9}$ All documented cases occurred within the last 9 years and 11 of 14 occurred within the last 2 years, which suggests a recent emergence in cardiology attributed to either increasing incidence, improving recognition, or both concurrently.

One common thread between all 14 cases is onset after fentanyl and/or MB administration. In the cardiac setting, fentanyl is used routinely for perioperative pain control and prevention of systemic increases in afterload. ${ }^{10}$ Its role in serotonin syndrome is due to opioid-mediated release of serotonin in the central nervous system. ${ }^{11} \mathrm{MB}$ is used in emergency cases of vasoplegia, which is severe hypotension with low systemic vascular resistance and baseline or increased cardiac output. ${ }^{12}$ Vasoplegia affects $8 \%$ to $24 \%$ of patients undergoing cardiac operations and has a mortality of $16 \%$ to $27 \% .{ }^{13}$ In patients with heart failure undergoing cardiac surgery, incidence is even greater: $27 \%$ in those with low ejection fraction and $42 \%$ in those undergoing LVAD placement. ${ }^{14} \mathrm{MB}$ has been shown to increase vascular tone and decrease vasoplegia duration and mortality in these situations. ${ }^{13}$ It is a powerful inhibitor of vasodilation but generally is considered a "last-resort" treatment because of its adverse side effects and increased morbidity. ${ }^{12,15,16}$ Serotonin syndrome is one of the concerns because of its ability to cross the blood-brain barrier and specifically inhibit the serotonin degrading enzyme monoamine oxidase A. ${ }^{17}$ Other concerns are decreased renal and mesenteric blood flow, cardiac arrhythmias, and increased pulmonary artery pressure. ${ }^{15,16}$

The second common thread among 13 of 14 cases in Table 1 is antidepressant use before hospitalization. The most common antidepressants are selective-serotonin reuptake inhibitors (SSRIs), serotonin and norepinephrine reuptake inhibitors, and tricyclics, which are all serotonergic agents. ${ }^{18,19}$ In Table 1, 5 different SSRIs and one serotonin and norepinephrine reuptake inhibitor are represented across the 14 cases, indicating drug class is a more important precipitating factor than any one drug brand. This medication risk is relevant to cardiology because depression is an exceedingly common comorbidity of heart disease, particularly heart failure. ${ }^{20,21}$ In a study using the Beck Depression Inventory score, the authors found $35.3 \%(n=374)$ of patients with congestive heart failure had depression. ${ }^{21}$ Similarly, a retrospective study of heart

\section{TABLE 2. The Hunter Criteria}

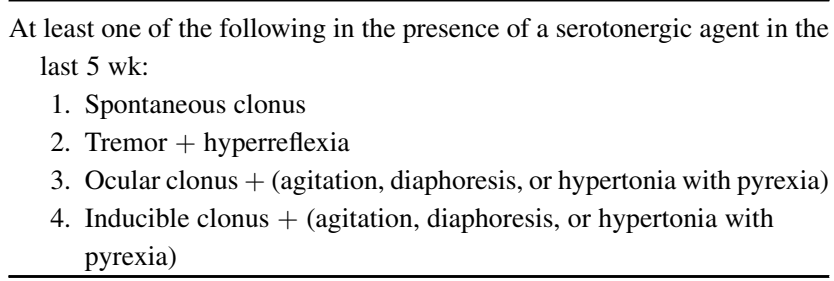

transplant patients found $38 \%$ were taking an SSRI at the time of surgery, ${ }^{3}$ which indicates a substantial number of cardiology patients are at increased risk for serotonin syndrome. This deserves recognition when considering the use of serotonergic agents such as fentanyl or MB.

If fentanyl or MB cannot be avoided in a patient taking a serotonergic antidepressant, it is essential to remain vigilant for signs of serotonin syndrome. The Hunter Criteria, summarized in Table 2, are used widely to identify clusters of symptoms that are highly sensitive $(84 \%)$ and specific $(97 \%)$ for serotonin syndrome. ${ }^{22-24}$ It applies to cases in which a serotonergic agent was used within the last 5 weeks, although onset typically occurs within 24 hours of a medication or dose change. In this case report, the patient displayed inducible clonus, hypertonia, and pyrexia, which met criterion 4 in Table 2. This diagnosis was reached with a high degree of certainty for multiple reasons: the Hunter Criteria has a specificity of $97 \%$ (low false positive rate), there is an appropriate close temporal relation between MB administration and symptom onset, and other common etiologies were excluded, such as intracranial hemorrhage, seizures, bacterial infection, and overt metabolic abnormalities. For these reasons, an exhaustive metabolic workup was not indicated.

In all cases of serotonin syndrome, the most important treatment is withdrawal of the causative agents. In mild cases, full neurologic recovery is expected within 24 to 72 hours with supportive care alone. ${ }^{24}$ In moderate and severe cases, benzodiazepines should be used to reduce agitation. Cyproheptadine is a serotonin $2 \mathrm{~A}$ receptor antagonist that is also advised, although its effectiveness in serotonin syndrome has not been definitively tested with randomized clinical trials. ${ }^{25}$ Critically ill patients with muscle activity driving temperatures greater than $41.0^{\circ} \mathrm{C}$ require neuromuscular paralysis and intubation. Prognosis generally is favorable if serotonin syndrome is recognized and treated early.

\section{CONCLUSIONS}

Serotonin syndrome is a life-threatening condition that is emerging in cardiology. A comprehensive understanding of the condition, as presented in this article, is needed to address the emergence and maximize prevention while minimizing response time. If concomitant serotonergic agents such as SSRIs, fentanyl, and MB cannot be avoided, vigilance for signs of serotonin syndrome is key as it can be fully reversed with early recognition and treatment.

\section{References}

1. Shanmugam G, Kent B, Baskett R. Serotonin syndrome following cardiac surgery. Interact Cardiovasc Thorac Surg. 2008;7:656-7.

2. Choudhury M, Hote MP, Verma Y. Serotonin syndrome in a postoperative patient. J Anaesthesiol Clin Pharmacol. 2011;27:233-5.

3. Grubb KJ, Kennedy JL, Bergin JD, Groves DS, Kern JA. The role of methylene blue in serotonin syndrome following cardiac transplantation: a case report and review of the literature. J Thorac Cardiovasc Surg. 2012;144:e113-6. 
4. Fugate JE, White RD, Rabinstein AA. Serotonin syndrome after therapeutic hypothermia for cardiac arrest: a case series. Resuscitation. 2014;85: 774-7.

5. Hanna ER, Clark JA. Serotonin syndrome after cardiopulmonary bypass: a case demonstrating the interaction between methylene blue and selective serotonin reuptake inhibitors. A A Case Rep. 2014;2:113-4.

6. Smith CJ, Wang D, Sgambelluri A, Kramer RS, Gagnon DJ. Serotonin syndrome following methylene blue administration during cardiothoracic surgery. J Pharm Pract. 2015;28:207-11.

7. Hencken L, To L, Ly N, Morgan JA. Serotonin syndrome following methylene blue administration for vasoplegic syndrome. J Card Surg. 2016;31:208-10.

8. Martino EA, Winterton D, Nardelli P, Pasin L, Calabrò MG, Bove T, et al. The blue coma: the role of methylene blue in unexplained coma after cardiac surgery. J Cardiothorac Vasc Anesth. 2016;30:423-7.

9. Wolvetang T, Janse R, Ter Horst M. Serotonin syndrome after methylene blue administration during cardiac surgery: a case report and review. J Cardiothorac Vasc Anesth. 2016;30:1042-5.

10. Broussard D, Donaldson E, Falterman J, Bates M. Anesthesia for left ventricular assist device insertion: a case series and review. Ochsner J. 2011;11:70-7.

11. Ailawadhi S, Sung KW, Carlson LA, Baer MR. Serotonin syndrome caused by interaction between citalopram and fentanyl. J Clin Pharm Ther. 2007;32: 199-202.

12. Hosseinian L, Weiner M, Levin MA, Fischer GW. Methylene blue: magic bullet for vasoplegia? Anesth Analg. 2016;122:194-201.

13. Levin RL, Degrange MA, Bruno GF, Del Mazo CD, Taborda DJ, Griotti JJ, et al. Methylene blue reduces mortality and morbidity in vasoplegic patients after cardiac surgery. Ann Thorac Surg. 2004;77:496-9.

14. Argenziano M, Chen JM, Choudhri AF, Cullinane S, Garfein E, Weinberg AD, et al. Management of vasodilatory shock after cardiac surgery: Identification of predisposing factors and use of a novel pressor agent. $J$ Thorac Cardiovasc Surg. 1998;116:973-80.
15. Weiner MM, Lin HM, Danforth D, Rao S, Hosseinian L. Methylene blue is associated with poor outcomes in vasoplegic shock. J Cardiothorac Vasc Anesth 2013;27:1233-8.

16. Evora PR, Ribeiro PJ, Vicente WV, Reis CL, Rodrigues AJ, Menardi AC, et al Methylene blue for vasoplegic syndrome treatment in heart surgery: Fifteen years of questions, answers, doubts and certainties. Rev Bras Cir Cardiovasc. 2009;24 279-88.

17. Oz M, Lorke DE, Hasan M, Petroianu GA. Cellular and molecular actions of methylene blue in the nervous system. Med Res Rev. 2011;31: 93-117.

18. Tousoulis D, Antonopoulos AS, Antoniades C, Saldari C, Stefanadi E, Siasos G et al. Role of depression in heart failure-choosing the right antidepressive treatment. Int J Cardiol. 2009;140:12-8.

19. Harris J, Heil JS. Managing depression in patients with advanced heart failure awaiting transplantation. Am J Health Syst Pharm. 2013;70:867-73.

20. Thomas SA, Chapa DW, Friedmann E, Durden C, Ross A, Lee MCY, et al Depression in patients with heart failure: prevalence, pathophysiological mechanisms, and treatment. Crit Care Nurse. 2008;28:40-55.

21. Jiang W, Alexander J, Christopher E, Kuchibhatla M, Gaulden LH, Cuffe MS, et al. Relationship of depression to increased risk of mortality and rehospitalization in patients with congestive heart failure. Arch Intern Med. 2001;161: 1849-56.

22. Dunkley EJC, Isbister GK, Sibbritt D, Dawson AH, Whyte IM. The Hunter Serotonin Toxicity Criteria: simple and accurate diagnostic decision rules for serotonin toxicity. QJM. 2003;96:635-42.

23. Boyer EW, Shannon M. The serotonin syndrome. N Engl J Med. 2005;352: 1112-20.

24. Ables AZ, Nagubilli R. Prevention, diagnosis, and management of serotonin syndrome. Am Fam Physician. 2010;81:1139-42.

25. Frank C. Recognition and treatment of serotonin syndrome. Can Fam Physician 2008;54:988-92 